\title{
A Psychoanalytical Interpretation of Ying-ying's Contradiction
}

\author{
Qu Jingyi (Corresponding author) \\ Nanyang Technological University, Singapore \\ Tay Qin Xuan \\ Nanyang Technological University, Singapore
}

Received: 16-02-2016

doi:10.7575/aiac.ijclts.v.4n.2p.45
Accepted: 23-03-2016

Published: 01-04-2016

\begin{abstract}
This study investigates Yuan Zhen's "The Story of Ying-ying" ("Yingying Zhuan") by means of Sigmund Freud's psychoanalysis. From a psychoanalytic perspective, Ying ying faces internal struggles between the ego and the id caused by her superego - this leads to her inconsistent behaviours. This contradiction encapsulates how any reasonable person would have felt, thus having an epoch-marking significance. Poems composed based on their love affair also reveal the social role of scholars under the reality principle, the underlying basis for the desertion of Ying-ying. Interpretation of the story using a combination of tale and poetry expands the Tang literati discourse on Ying-ying's contradictory behaviours.
\end{abstract}

Keywords: Psychoanalysis, Contradiction, “The Story of Ying-ying”, Poems relevant to Ying-ying

\section{Introduction}

Sigmund Freud (1856-1939), the father of psychoanalysis, not only made vast contributions to psychology, but also to the field of literature. His works can be closely linked to the analysis of classical literary works to delve deeper into the human mind. Yuan Zhen's 元穞 (779-831) “The Story of Ying-ying” (“Yingying Zhuan” 鶯鶯傳1) tells of a love affair between a young scholar named Zhang 張生 and a maiden from a good family Ying-ying in China Tang Dynasty(618907). The story had a lasting impact on later Chinese literature, yet literature review reveals the lack of analysis on Ying-ying's inner feelings, which can be developed using Freud's psychoanalysis. As such, this paper will conduct a critical analysis from the psychoanalytic perspective on "The Story of Ying-ying", and tie in relevant poems to provide readers with a more holistic understanding of the deeper mental activities that take place in women portrayed in the love tales of Mid-Tang. By placing an emphasis on psychology to analyse the influential literary prose fiction, this paper develops new insights to classical literature.

The crux of analysis lies in the dilemma Ying-ying experiences throughout the story, due to the decisions she has to make in the pursuit of love. Her psychological change from rejection to embracing love, and from presenting herself to refusing to meet Zhang, can be mainly attributed to the internal conflict between her ego and id. This aspect of her erratic behaviour has received scholarly attention, and many studies have been done on it. However, the originality of this paper is in using psychoanalysis from Ying-ying's perspective to delve deeper into the reason behind her ambivalence, and bringing her character to life by showcasing her inner feelings to readers. Main psychoanalytical theories used are the psychoanalytic theory of personality, psychoanalytic libido and the interpretations of dream. Given that this tale is an autobiographical account of the author's life, relevant poems written on the love story between Yingying and Chang will also be analysed to provide a full insight into the birth of this literary classic.

The key to the continuous appeal of "The Story of Ying-ying" lies in the subtle change in emotions of Ying-ying, portraying her as a unique and unmatched female character in the portraits of Tang dynasty tale. The story emphasises the contradictory behaviours of Ying-ying, thereby reflecting the complexity and diversification of her personality. This section of the paper will analyse the story from the psychoanalytic perspective in two parts corresponding to the development of the storyline.

\section{Rejection to Embracing Love}

Under the influence of the Confucian code of ethics, the initial appearance of Ying-ying is a girl who is "very strict that not even her elders could suggest anything improper to her"2 貞慎自保, yet the appearance of a young scholar named Zhang stirred her emotions within a short period of four days. At the start, Ying-ying defied her mother's orders to meet their benefactor Zhang, which can be understood as her trying to uphold her strict observance of propriety. At the dinner, she "looked angrily straight ahead"3 凝睇怨絕and was unfazed when Zhang "tried to make conversation with her"4 稍以導之, portraying her as a dignified person who does not express her emotions easily. This could be an indication that her superego and $\mathrm{id}^{5}$ are already at odds. On the other hand, Zhang was utterly besotted with her as "her beauty was so extraordinary, so radiant it took the breath away" 顏色豐異, 光輝動人. According to a Bulgarian playwright Vasilev Orlin, a woman's beautiful body “will make a man have a dizzy spell and evoke their natural 
emotions"7 會使男子頭軍目眩, 激起他們的自然感情, hence it is a natural reaction for Zhang's sexual desire to be aroused.

Zhang heeded the advice of her maid Hong Niang紅娘 and went on to write a love poem for Ying-ying, strategically displaying the talented side of him. This move stirred the repressed emotions within Ying-ying that was previously deep in slumber, urging her to reply with the poem "Bright Moon on the Night of the Fifteenth". When Zhang made a visit to her house, he was unexpectedly greeted with an "upbraid" 數落by Ying-ying. The reason behind this is the internal struggle between Ying-ying's primal desire and her moral values upheld by superego, resulting in the repression of the id. As such, Ying-ying's contradictory actions is a classic illustration of the psychological state of most respectable ladies in the Tang dynasty who face a dilemma, accurately depicting their reservations while battling with inner desires.

As Sigmund Freud has pointed out in the "The Relation of the Poet to Daydreaming", "unfulfilled desires expressed by women are mainly sexual and erotic"8 女性所表現的未被滿足的慾望主要是性慾、色情的, causing Ying-ying to voluntarily offer herself to Zhang just days after rejecting him. This drastic change in events is driven by the powerful force of libido ${ }^{9}$, where her ego is no longer able to contain the burning desire of id. Once Ying-ying yields to the temptation which is not socially acceptable, an immediate change can be noticed about her. However, defying social norms by losing her chastity before marriage do not necessarily mean that Ying-ying is what some researchers view her as a prostitute. On the contrary, it brings out her innocence as a teenage girl. According to Gaozi's告子 (BCE420BCE350), assertion “eating and sex are xing” 食色性也. Sexual instinct is the innate tendency of every human being, thus Zhang is the one who wakens the young girl's desire for love. The psychological epiphany of Ying-ying which results in her change of heart reflects the moral constraints a woman in the Tang dynasty faces in pursuit of her dreams.

\section{Sacrificing Chastity to Refusal}

Regardless of how beautiful dreams may be, it will wake up to reality one day, and the same will be applied to this pair of ideal lovers. When Zhang first left the capital to participate in the literary examinations, she "made no objections at all, but the look of pain on her face was very touching”10 崔氏宛無難詞, 然而愁怨之動容矣, underlining a conscious effort to hide her emotions. The turning point of their relationship is tied to his departure, as he has to choose between love and career, adhering to either the pleasure principle or the reality principle. Sigmund Freud mentioned that "Pleasure principle is the psychological tendency to gravitate towards pleasure and avoid hardship, whereas reality principle is a human's grasp of the real world." 11 Hence it would be a more rational choice for Zhang to choose to follow the reality principle ${ }^{12}$. Besides, Ying-ying is aware that her social status no longer matches that of Zhang, especially if he succeeds in the literary examinations. This is why she did not accede to Zhang's request to hear her play the musical instrument before leaving, indicative of her tenacity in trying to hold back her feelings.

On the second time Zhang left for the capital, Ying-ying told Chang "to seduce someone and then abandon her is perfectly natural, and it would be presumptuous of me to resent it”13 始亂之, 終棄之, 固其宜矣, 愚不敢恨. Her response seem to indicate that she has accepted the truth of being abandoned by her lover. Everything appears to be calm on the surface, but deep within her heart, intense emotions overwhelm her heart and mind. She expresses her outburst of repressed feelings through "Rainbow Robe and Feather Skirt"14 霓裳羽衣until “After a few notes, her playing grew wild with grief until the piece was no longer recognizable.” 15 不數聲, 哀音怨亂, 不復知是曲也, expressing her reluctance to part with Zhang. German philosopher Arthur Schopenhauer (1788-1860) argues in his book that "Unlike other forms of art, music is not a copy of philosophy, but a copy of the world itself..... the reason why the power of music is much greater than other forms of art”16 音樂根本不像其他藝術一樣, 它不是理念的摹本......音樂的效果要比其他藝術有力的多的緣故, thus Ying-ying gathers strength from music to release her grief and pent-up emotions, reflecting the helplessness of women in the male-dominated society.

Memories created together last a lifetime, akin to a lasting birthmark - Ying-ying is unable to erase Zhang from her conscious mind. The letter sent to Zhang after his departure represents her everlasting love and longing for him. Her feelings are similar to the couplet written by Wang Chang-ling 主昌齡(698-756) “Surprised to find the color of willows by the roadside, she regrets letting her man go after a marquisate"17 蕩舟遊女滿中央, 采菱不顧馬上郎, which represents the woman's longing for her husband. Meticulous thought put into crafting the letter and selection of gift is indicative that she "still cannot suppress her love and hope" 18 . Her unwavering feelings for him were not appreciated in return, as he summarized his affair with Ying-ying as an instance of a dangerous encounter with "women endowed by Heaven with great beauty"19 尤物. Socially prescribed rules state that "to abandon a poor girl and marry one of higher social status is a socially acceptable behaviour"20 捨棄寒女, 而別婚高門, 當日社會所公認之正當行為也, thus Zhang's superego propels him to take on a social role by finding a more advantageous match, whereby he could further his career through marriage. By doing so, he represses his feelings for Ying-ying to his subconscious mind. Therefore, his self-justification for abandonment works to dispel the internal conflict deep within his heart.

Zhang's subsequent attempt to see Ying-ying despite both of them being married reflects his yearning for her. On the other hand, Ying-ying's refusal to meet Zhang can be understood as an attempt to avoid arousing her libido, which must have lain dormant before he entered her life ${ }^{21}$. The phrase "Any love you had then for me, will do for the one you have now"22 還將舊時意, 憐取眼前人speaks about the pain and struggle Ying-ying once experienced, and also brings out her realisation of the harsh reality. Their love brings to mind that under the reality principle, "The course of true love never did run smooth" ${ }^{23}$, yet it is Ying-ying's character that brings life to this otherwise ordinary love tale. 


\section{A Psychoanalytical Interpretation of Poems Relevant to Ying-ying}

Achievements of poetic creations reaches its pinnacle of development in the Tang dynasty, thus a feature characteristic of Tang dynasty tales is the integration of poems to bring out the best in each other. A major reason for the literary achievement of "The Story of Ying-ying" can be attributed to the poems found in the tale.

\subsection{Poetic Interpretation of "The Story of Ying-ying"}

Many aspects of the tale include the ingenious integration of poems, which propels the development of the story and implicitly expresses the inner world of the fictional character. In "The Story of Ying-ying", poems composed include “Spring Song” 春詞, “Bright Moon on the Night of the Fifteenth” 明月三五夜, “Young Miss Ts“ui” 崔娘詩 and Yuan Zhen's “Encounter with an Immortal” 會真詩三十韻. The two stanzas of Spring Song written by Zhang caused Yingying's emotions to overrule reason, and sacrifice her chastity in the name of love. Therefore, this poem subtly reflects the psychological processes of a teenage girl in anticipation of her lover's arrival, achieving its initial goal to "seduce her with a love poem"24 喻情詩以亂之.

Ying-ying's response to Zhang's love poem "Bright Moon on the Night of the Fifteenth" clearly indicates an intention of a rendezvous, revealing her romantic interest for Zhang. While waiting in the Western chamber, her heart is already in a "half-opened" 半開state, indicative of her underlying desire for him. The following lines "Sweeping the wall the flower shadows move: I imagine it is my lover who comes” 撫牆花影動, 疑是玉人來 gives us a glimpse into the inner world of Ying-ying, as it vividly expresses her anxiety and longing to meet her lover. In contrast to the time when they first met, it is clear that Zhang has awakened Ying-ying's id, foreshadowing her loss of chastity in the later development.

The poem Yuan Zhen wrote "Encounter with an Immortal" serves to fill readers with more details regarding their rendezvous. From the title of the poem, it signifies an encounter with a woman as beautiful as a fairy ${ }^{25}$. The first ten couplets uses a complete narrative method to describe Ying-ying's appearance, where narratives such as "thin mist" 薄霧and “light breeze” 輕風create a dreamy atmosphere. “An allusion of Dengtu Zi” 登徒子好色賦is also borrowed as an analogy of Yuan Zhen's desire for her. The poem reaches its climax in the next ten couplets, fully showcasing the psychological process of how Ying-ying succumbs to the temptation of her innermost sexual desires. When faced with teasing from Zhang, she “rejects a bit at first, but her yielding love is already disclosed” 戲調初微拒, 柔情已暗通, making known that her id has been roused at this point of time. This puts her into an internal struggle between her superego and id, caused by her apprehensions about societal values and desire to go against the Confucian code of ethics. Hesitant actions "lowered locks" 低襄and “returning steps" 回步capture her conflicting thoughts. After a bout of internal struggles, Ying-ying finally relents and "climbs into bed". The last ten couplets depict the state that Yuan Zhen is immersed in after the dreamlike experience. His yearning for her lingers on even after her departure, but "Hsiao Shih stays in his chamber" 蕭史在樓中reveals the true nature of their union: an ephemeral encounter with the goddess ${ }^{26}$. In summary, Yuan Zhen's repressed sexual desire sublimates into poetic works, satisfying his id in a socially acceptable way. A poetic appreciation of Ying-ying reaffirms her as the locus of tension between romance and propriety ${ }^{27}$.

\subsection{Yuan Zhen's Poems: A Reminiscence of Ying-ying}

In the collection of Yuan Zhen's poems, some closely correspond to Ying-ying, revealing traces of his contradictory and complex inner world. According to research by scholars, there are thirty seven poems relevant to Ying-ying in "The Collected Works of Yuan Zhen” 元稹集, and can be classified into three essential contexts: initial encounter with Yingying to abandonment; bidding farewell to each other; and pine in her absence ${ }^{28}$. As the last stage of his works gives an accurate impression of Yuan Zhen's psychological activities, this paper will focus on his poems during this period by using the analysis of dreams ${ }^{29}$ to analyse “Dream of Wandering in Spring” 夢遊春七十韻, “Dreaming of Old Times" 夢昔時and “For Wife Liu [Chen] and Ruan [Zhao]” 劉阮妻二首accordingly.

It might be true that Yuan Zhen chose to abandon Ying-ying, yet the notion of a dream voyage reveals his subconscious yearning for her even after marriage. To Sigmund Freud, the intensity of emotions experienced in a dream is no less than that of a conscious experience ${ }^{30}$, which implies that the world of imagery is similar to reality. In his dreams, his encounter with a girl who was “wearing an everyday dress and no makeup on her smooth face” 鮮妍脂粉薄, 暗淡衣裳故suggests that this scene is a flashback of their initial encounter. From this, it can be seen that the image of Ying-ying in his subconscious mind is one of grace and poise, entirely different to that of a kingdom wrecker. Therefore, this poem can be seen as a condensation ${ }^{31}$ of their experiences, written out of his longing for Ying-ying.

Under the subjectivity of reality principle, Yuan Zhen turns to dreams in order to fulfil wishes not met in reality. Albeit a dream, the scene of their meeting in "Dreaming of Old Times" is a secondary revision ${ }^{32}$ of his unconscious longing for her by reminiscing past happy moments. These moments do not last long, as "What matter serves to disrupt my feelings, to cause yet another separation” 何事來相感，又成新別離speaks of his feelings of helplessness towards reality which sets this pair of lovers apart. Besides, "For Wife Liu [Chen] and Ruan Zhao" uses dream as a literary representation of the love between them, one that is hard to come by. However, reality leaves him with no choice but to serve as an official, leading to psychological imbalance. Emotions act as a source of motivation for scholars to sublimate their feelings into literary creations. This translates into a stream of consciousness which reflects the true nature of Yuan Zhen's feelings for Ying-ying. 
4.3 Paired Phrases: "The Story of Ying-ying", and "Song of Ying-ying",

Tang dynasty tales takes on an ideal combination of verse and tale, leading to the emergence of a phenomenon described by Chen Yin-que 陳寅恪as “A person uses prose to compose a tale, the other person sings about it using a verse" 33 一人用散文作傳, 一人以歌行詠其事. An official Li Shen 李紳 (772-864) found “The Story of Ying-ying” 鶯鶯歌 to be remarkable and consequently "composed a 'Song of Ying-ying' to commemorate the affair" 公垂卓然稱異, 遂為《鶯鶯歌》以傳之. To date, only four verses of the “Song of Ying-ying” remains, which is included in “Medley of the Western Chamber"34 西廂記主宮調. Although we are no longer able to get a glimpse of the original form, the "Song of Ying-ying" is written from Li Shen's viewpoint as a spectator of their love affair, thus it offers a correspondence to the tale.

As described in the poem, Ying-ying has the beauty of “weeping flowers blossom upon her smile” 垂楊綻金花笑日” and “looks pure as snow” 霜姿素蓮質, unknowingly sparking off Yuan Zhen's flames of desire for her. Relatively, their initial encounter has aroused Ying-ying's libido, yet she is conditioned by her Confucian upbringing to respect propriety $^{35}$. Furthermore, “never did she step out when flowers blossom” 芳草花時不曾出 implies that she rarely has a chance to interact with the opposite sex, hence she may not be aware of her feelings for him at this point of time. As such, during the invitation to dinner she does not know how to respond to his advances and fears that her feelings will be disclosed, which corresponds to her taciturn in the tale.

Li Shen subsequently portrays the internal conflict within Ying-ying through a series of actions. Driven by her hunger for love, she attempts to "trim her red dress and compose a poem on it" 剪破紅綃裁作詩 in order to convey her love across to Yuan Zhen, in hopes of satisfying her primitive sexual desire. This appears to be a bold move in the pursuit of love, yet it takes place in secrecy as "in the poem there are concealed meanings to the young man, he knows and secretly heads to the depth of flowers” 詩中報郎含隱語，郎知暗到花深處, homologous with Hong Niang as their intermediary in the original text. As a girl of modest upbringing, she has to take into consideration the Confucian code of ethics and exercise prudence when expressing her love. Regardless, what makes Ying-ying endearing is her willingness to risk parental and social disapproval to chase after what she believes $i^{36}$. In summary, from the remaining verses of "Story of Ying-ying", Li Shen's stand towards their love affair suggests that he is in favour of women pursuing after their own love and is full of admiration for Ying-ying.

\section{4 “Contemporaries” Viewpoint of Zhang's Abandonment}

In the male-dominated Tang society, the response of contemporaries to Zhang's act of abandonment is "conceded that Zhang had done well to rectify the mistake” 善補過者, resulting in the wide circulation of the love story. Poets such as Bai Juyi 白居易and Yang Ju-yuan 楊巨源 (775-?) made compositions of their love affair. As an autobiography, Yuan Zhen tries to rationalize his desertion of Ying-ying on moral grounds, as an attempt to resolve his inner conflict through social affirmation. Contrary to earlier descriptions of Zhang as "firm and self-contained, and capable of no improper act”內秉堅孤, 非禮不可入, his behaviour appears improper and requires denunciation in the virtue of morality.

From the literary works written based on the love affair between Zhang and Ying-ying, it can be concluded that most of them take pity on Ying-ying's predicament. For instance, Yang Chu-yuan wrote a quatrain “Young Miss Cui” 崔娘詩 upon seeing Ying-ying's letter which was filled with grief. The last verse "A letter from the Hsiao girl, brokenhearted" 斷腸蕭娘一紙書, emphases the emotional turmoil she went through due to Zhang's desertion, in turn revealing his pity for her and also women of the same plight. An underlying reason for poets to take sympathy on Ying-ying is a natural reaction of the superego, which is the "higher, moral, supra-personal side of human nature" 37 . However, it does not necessarily mean that society negates Zhang for his lack of moral rectitude. In the same poem by Yang Ju-yuan, "A romantic young man filled with thoughts of love” 風流才子多春思 suggests that it is only natural for gifted scholars like Zhang to be involved in romantic love affairs. In spite of this, Tang scholars are deeply aware of the fact that they are subjected to the constraints of the moral principles of Confucianism when they seek the pleasure principle. As mentioned by Tang poet Bai Juyi in "His Lady Li"李夫人, “Alive and enchanted, dead and deluded, these women of rare beauty enchant people forever haunting their lives”生亦惑，死亦惑，尤物惑人忘不得 warns of the dangers of indulging in the satisfaction of the id. This reflects the notion that every scholar should make preparations for their future role in society, thus superego drives Zhang to abandon Ying-ying in consideration of his societal role.

\section{Conclusion}

To conclude, with Ying-ying as the spokesperson, "The Story of Ying-ying” is an outstanding masterpiece in the Tang dynasty tales which pulls at the heartstrings of readers. Her contradictory behaviours in the pursuit of love brings her internal struggles to life, very much similar to a play within a play. Throughout the development of the story, the subtleties in emotional fluctuation vividly and thoroughly expresses her contradiction, hence it can be seen as a model of psychology in terms of literature. As a model of “scholar and beauty" (caizi jiaren 才子佳人) literature, the love between Zhang and Ying-ying burgeons from their sexual desire for each other, thus Ying-ying's hunger for love drives her to pursue the love she yearns for. Yet, the reality of principle throws her into an inner struggle between the superego and id as she is conscious of the mismatch in their social status. What makes Ying-ying endearing is that despite the obstacles in their love, she does not bow to reality. Instead, she overcomes the constraints of the Confucian code of ethics and continues to shine in her own way.

In light of Ying-ying's epoch-marking significance, the passing of time did not diminish her stature in the portraits of Tang dynasty tales. If Ying-ying is placed in the context of a modern society, her contradictory feelings towards love remain close to the modern day audience. As much as a romantic relationship in the modern era is no longer bound by 
the moral principles of Confucianism, many still harbour conflicting thoughts under the subjectivity of the reality principle. It is noteworthy that relationships seem to lack the resolve and commitment Ying-ying demonstrates in her pursue of true love. In retrospect, the image of Ying-ying in reader's mind is akin to a jar of old wine, one that leaves a rich aftertaste and withstands the test of time, worthy to be known as a legendary person.

\section{References}

Chen, Y. (2001). Manuscript on Annotations and Commentaries of the Poetry of Yuan (Zhen) and Bai (Juyi). Beijing: San lian shudian.

Hsia, C. T. (2004). C. T. Hsia on Chinese Literature. Columbia: Columbia University Press.

Freud, S. (1952). On Dreams. New York, NY: W.W. Norton \& Company.

Freud, S. (1960). The Ego and the Id. New York, NY: W.W. Norton \& Company.

Freud, S. (1964). The Standard Edition of the Complete Psychological Works of Sigmund Freud. London: The Hogarth Press.

Freud, S. (1966). Introductory Lectures on Psycho-Analysis. New York, NY: W.W. Norton \& Company.

Freud, S. (2000). The Interpretation of Dreams. Beijing: Shangwu yin shu guan.

Huang, S. Z. (1992). “A Study on Yuan Chen's 'Poem of Ying-ying' — also on 'A work may not be reflective of the writer'”. On the Study of Tang Literature, Vol. 5, pp. 440.

Hightower, J. R. (1973). "Yuan Chen and 'The Story of Ying-ying"”, Harvard Journal of Asiatic Studies, Vol. 33, pp.90-123.

Lee, J. J. (1982). Wang Ch'ang-ling. Boston: Twayne Publisher.

Liu, Y. P. (1996). “Repress, Repression and Supression: A Study on 'Fei Bu Zhuan', 'The Story of Huo Xiaoyu' and 'The Story of Ying-ying"'. Report on the Eighth Conference of the Tang Literature Association of China and International Symposium on Tang Literature, Vol. 7, pp.136-153.

Luo, M. (2005). “The Seduction of Authenticity: 'The Story of Ying-ying””. Brill Academic Publishers, Vol. 7, No.1, pp.65.

Palandri, A. J. (1974). "Yuan Chen's 'Hui Chen Chi’: A Re-Evaluation”. Pacific Coast Philology, Vol. 9, 56-61.

Shakespeare, W. (1600). A Midsummer Night's Dream. London: Stationers' Company.

Tsai, K. (2004). "Ritual and Gender in the 'Tale of Li Wa"”. Chinese Literature: Essays, Articles, Reviews (CLEAR), Vol. 26, pp.99-127.

Yan, L. (2010). “Biography of Li Shen and Research of his Work”. Soochow University Master's Thesis.

Xing, J. (2014). “The Tang Poetry in the Tang Legend”. Liaoning Normal University Master's Thesis.

Zeng, Z. (2011). “A Study on Yuan Chen's Love and Marriage and his Relevant Works”. Jiangxi Normal University's Master's Thesis.

\section{Notes}

${ }^{1}$ Alternative titles for the story include “Chuanqi” 傳奇and “Huizhen ji” 會真記. For a detailed discussion of the tale’s textual history, refer to Li Jianguo 李劍國, Tang Wudai Zhuguai Chuanqi Xu Lu 唐傳奇五代敘錄 (Tianjin: Nankai daxue chubanshe, 1993), 310-14.

${ }^{2}$ Hightower, 1973, p 95.

${ }^{3}$ Hightower, 1973, p. 94.

${ }^{4}$ Same as above.

${ }^{5}$ Freud, 1960, p. 17-31. Id "behaves as though it were the unconscious", and is free from external restraints while it follows the pleasure principle. On the other hand, superego is the "the higher, moral, supra-personal side of human nature". It is responsible for the repression of id, so as to align actions with societal values.

${ }^{6}$ Hightower, 1973, p. 94.

${ }^{7}$ Huang, 1992, p. 440.

${ }^{8}$ Liu, 1996, p. 146.

${ }^{9}$ Hightower, 1966, p. 387. Libido is a force "by which the instinct manifests itself" and is full of sexual desire. It follows two principles: pleasure principle and reality principle.

${ }^{10}$ Hightower, 1973, p. 97.

${ }^{11}$ Freud, 1964, p. 223.

12 Hightower, 1966, p. 404. A halt and retrogression in sexual development cause humans to realise that id goes against morality. When this happens, reality principle will overrule pleasure principle.

${ }^{13}$ Hightower, 1973, p. 97.

${ }^{14}$ Hightower, 1973, p. 98. 
${ }^{15}$ Same as above.

${ }^{16}$ Liu, 1996, p. 150.

${ }^{17}$ Lee, 1982, p. 107.

${ }^{18}$ Palandri, 1974, p. 56-61.

${ }^{19}$ Hightower, 1973, p. 102. The term 尤物 seems to have a wider connotation than a "beautiful woman". Here it is associated with it Tso Chuan occurrence (Chao 28): “Great beauty entails great evil... Where there are beautiful creatures, such as can move men, if they are not moral and virtuous, there will inevitably be disaster."

${ }^{20}$ Chen, 2001, p. 116.

${ }^{21}$ Palandri, 1974, p. 59.

${ }^{22}$ Hightower, 1973, p. 103.

${ }^{23}$ Shakespeare, 1600, p. 132-140.

${ }^{24}$ Hightower, 1973, p. 95.

${ }^{25}$ Zeng, 2011, p. 12.

${ }^{26}$ Tsai, 2004, p. 118.

${ }^{27}$ Luo, 2005, p. 65.

${ }^{28}$ Huang, 1992, p. 439.

${ }^{29}$ Freud, 1952, p. 15-17. Dreams are "a sort of substitute for the thought processes, full of meaning and emotion". After Sigmund Freud's investigation on case studies of children's dreams, he found out that dreams serve as "simple and undisguised wish fulfilments".

${ }^{30}$ Freud, 2000, p. 461.

${ }^{31}$ Freud, 1952, p. 27-50. Condensation is one of the processes of dreams. This term refers to the formation of dreams by "two or more impressions or experiences".

${ }^{32}$ Secondary revision is one of the processes of dreams. This term refers to the formation of dreams by "modification into pictorial form".

${ }^{33}$ Xing, 2014, p. 6.

${ }^{34}$ Yan, 2010, p. 31.

${ }^{35}$ Hsia, 2004, p. 92.

${ }^{36}$ Same as above.

${ }^{37}$ Freud, 1960, p. 31. 